\title{
Employees Expectations from Hr Services -A Study
}

\author{
Dr. Abdul Hakim**, Swati Shukla* \\ ${ }^{1,2}$ A.P.S University, Rewa (M.P.)
}

\begin{abstract}
Human resource management (HRM) is the strategic and coherent approach to the management of an organization's most valued assets - the people working there who individually and collectively contribute to the achievement of the objectives of the business. HRM means employing people, developing their capacities, utilizing, maintaining and compensating their services in tune with the job and organizational requirement.

This research paper discusses the concepts of HR services focusing the expectations of the employees of the concerned organization such as promotion of knowledge participation, effective $n$ efficient communication, friendly behavior of $H R$, proper feedback system etc. paper also discusses the need to be more human in dealing with the internal customers i.e., employees.
\end{abstract}

\section{Introduction}

Human Resource Services means the services which are provided by HR department to its internal customers meant by employees of the organization and to other departments as HR department is administrative as well as a service department. Human resource department is one of several departments which are vying for input of the strategic level at the decision making process within organization. Human resource departments are the entities organizations form to organize people, reporting relationships, and work in a way that best supports the accomplishment of the organization's goals. Human resource department is devoted to providing effective policies, procedures, and people-friendly guidelines and support within companies. Additionally, the human resource function serves to make sure that the company mission, vision, values or guiding principles, the company metrics, and the factors that keep the company guided toward success are optimized.

The Human Resource Services/Department deals with management of people within the organization. There are a number of responsibilities that come with this title. First of all, the Department is responsible for hiring members of staff; this will involve attracting employees, keeping them in their positions and ensuring that they perform to expectation. Besides, the Human Resource Department also clarifies and sets day to day goals for the organization. It is responsible for organization of people in the entire Company and plans for future ventures and objectives involving people in the Company.

Research has shown that the human aspect of resources within an organization contributes approximately eighty percent of the organization's value. This implies that if people are not managed properly, the organization faces a serious chance of falling apart. The Human Resource Department's main objective is to bring out the best in their employees and thus contribute to the success of the Company. Organization subscribes to the belief that efficiency, effectiveness and success of the organization depends largely on the skills, abilities and commitment of the employees who constitute the most important asset of the organization.

\section{Objective of the study}

口 To understand the basic needs and wants of employee from Services of HR.

a To measure internal customer's (Employees) satisfaction with service effectiveness of various service function.

- To collect best possible suggestions in order to make services more effective.

\section{Research Methodology} method.

Keeping in view the research evidence and objective it is found suitable to go through descriptive study

The present study is based on primary data. Primary data has been collected from respondents through questionnaires. In order to elicit the expectations of employees form HR services, a structured questionnaire having open as well as closed ended questions has been administered among a sample size of 150 respondents in an organization.

Simple percentage analysis has been used as the tool of analysis.

\section{Need of the study}

It is very important to understand the importance of Human Resource Management's functions and its services in a big public sector organization. The nature of job and the information obtained would help to relate 
data and find efficiency and correlation about sharing best practices. The parameters undertaken in the study are the most needed element for the effectiveness of each of the section of HR department; This would help to identify the privilege and shortcoming that may exists in the organization. This study would also help in knowing the expectations and problems of employee with reference of HR Services and also help to enhance the effectiveness of HR Services and to improve them by going through the suggestions of employees.

\section{Limitations of Study:}

i) The sample was confined to 150 respondents. So this study cannot be regarded as "full -proof" one.

ii) Some respondents hesitated to give the actual situation; they feared that management would take any action against them.

iii) There was a fear of reprisal among the employees to reveal their personal feelings and the result may not reflect the actual satisfactions.

iv) The findings and conclusions are based on knowledge and experience of the respondents sometime may subject to bias.

\section{Conclusion}

HR department is one of the major parts of any organization. Its goal is to maximize the productivity of an organization by optimum utilization \& improving effectiveness of its employees while simultaneously improving the work life of employees and treating employees as valuable resources. Human resource managers attempt to determine future HRM activities and plan for the implementation of HRM procedures to help companies realize their goals.

During research there was a questionnaire provided to a number of employees to analyze my topic which was EFFECTIVENESS OF HR SERVICES after going through the responses given by the employees and their analysis the following is concluded-

口 Behavior of HR employees is friendly and they are patient in dealing with employee and in clarifying their doubts and queries and helping as far as they can.

- They are competent and well trained in performing their duties.

a They take regular feedback and conduct surveys to know about employees' needs and problems to overcome with them.

\section{Attention Towards:-}

- The concerned officer must inform all the employees about what's going on in the company regarding up-coming facility which is provided by the organization.

- Share Knowledge, Information and expertise with others and respect knowledge and expertise of others.

- Communicate about anything going wrong or getting delayed to all concerned. Especially regarding HRissues.

\section{Suggestions}

a HR Executives should try to be friendlier with the employees of other department so that they can have a better mutual relationship with them and also enable employees to know the Responsibilities \& Challenges of their job. It would also be very beneficial to develop a positive attitude of employees towards HR Department.

HR-Department needs to be more human in dealing with the employees as it's not the services but the mode of delivery of the service that matters.

- Some employees have also stated that many of their queries aren't answered, so management needs to be more patient and active to correct the above problem.

a As most of the transactions are through SAP, one needs to have proper knowledge about the way it is operated for leaves purposes and for this regular awareness programs are to be conducted.

- Lastly, the management should always keep in mind that they are actually for the employees and their services.

a Communication meeting at departmental level should be done on regular basis in the presence of HR representative for sharing company's information etc.

- HR Department may take employees suggestions if required in order to make their services more effective \& to improve their weak areas.

- More positive alterations in future will make HR Services more effective. 


\section{References}

[1]. www.citehr.com

[2]. www.chrm.com

[3]. www.csmworld.com

[4]. http://en.wikipedia.org/wiki/Human_resource_management

[5]. http://expertscolumn.com/content/human-resource-management-nature-scope-objectives-and-function

[6]. http://www.business.com/directory/human_resources/outsourcing/hrms_hris.

[7]. http://www.encyclopedia.com/topic/Human_resource_management.aspx

[8]. http://www.sciencedirect.com/science/article/pii/S1053482209000461

[9]. http://www.businessdictionary.com/definition/recruitment.html

[10]. Aswathappa. K, human resource management Text \& cases: mc Graw Hill Education Pvt.Ltd.(2003)

[11]. RaoSubba. P, human resource management \& industrial relations (text, cases and games): Himalaya publishing house (2000) 